\title{
Responses of hardwood regeneration to fire in mesic forest openings. I. Post-fire community dynamics
}

\author{
Eric L. Kruger and Peter B. Reich
}

\begin{abstract}
The influence of fire on the regeneration ecology of northern red oak (Quercus rubra L.) and sympatric tree species was examined in mesic hardwood stands in southwestern Wisconsin. A plot in each of four openings was burned in the spring of 1989 and 1990. Density and height growth of tree regeneration, and leaf area index and percent cover of all plant growth forms were monitored on burned and nonburned plots in both years. Tree height growth was also measured in 1991. Fire substantially decreased tree regeneration density, and grasses and sedges became the most abundant vegetation on burn plots. Post-fire survival varied among the most common tree species. Densities of Acer saccharum Marsh. and Ostrya virginiana (Mill.) K. Koch decreased by more than $80 \%$, while those of Q. rubra and Carya cordiformis (Wangenh.) K. Koch increased or were unaffected. Net 2-year height growth decreased by $65 \%$ or more on burn plots for all of the common tree species except Q. rubra and C. cordiformis, which experienced losses of $25-35 \%$. The differential effects of fire on species survival and growth enhanced the competitive status of Q. rubra. In the absence of fire, it was uncertain whether $Q$. rubra would maintain a dominant or codominant position in the canopy of these developing stands.
\end{abstract}

\begin{abstract}
Résumé : L'influence du feu sur l'écologie de la régénération du chêne rouge (Quercus rubra L.), et des espèces forestières sympatriques, a été évaluée dans des peuplements mésiques de feuillus du sud-ouest du Wisconsin. Au printemps des années 1989 et 1990, une parcelle située à l'intérieur de chacune de quatre ouvertures a été brûlée. Au cours de ces deux années, on a mesuré la densité et l'accroissement en hauteur de la régénération des espèces forestières, de même que l'indice de surface foliaire et le pourcentage de couverture de toutes les formes végétales dans les parcelles brûlées et non brûlées. Une mesure de l'accroissement en hauteur des arbres a également été réalisée en 1991. Le feu a produit une baisse substantielle de la densité de la régénération des espèces forestières. Dans les parcelles brûlées, les herbacées et les carex sont devenus les plantes les plus abondantes. Pour les espèces forestières les plus communes, la survie après feu était variable. Les densités de Acer saccharum Marsh. et de Ostrya virginiana (Mill.) K. Koch ont été réduites de plus de $80 \%$ alors que celles de Q. rubra et de Carya cordiformis (Wangenh.) K. Koch ont augmenté ou sont demeurées semblables. Pendant cette période de 2 ans, l'accroissement net en hauteur de toutes les espèces forestières communes était inférieur, dans les parcelles brûlées, de $65 \%$ ou plus, à l'exception de Q. rubra et de C. cordiformis qui ont subi des pertes de l'ordre de 25 à $35 \%$. Les effets différentiels du feu sur la survie et la croissance des espèces ont rehaussé le statut concurrentiel de Q. rubra. En absence du feu, il était incertain que Q. rubra pourrait maintenir une position dominante ou codominante dans le couvert forestier de ces peuplements en devenir.

[Traduit par la Rédaction]
\end{abstract}

\section{Introduction}

The prevalence of northern red oak (Quercus rubra L.) and several congeners is steadily declining in forests of eastern North America (e.g., Pallardy et al. 1988; Spencer and Kingsley 1991; Stephens and Ward 1992). As mature oak stands are harvested or succumb to various stresses, ensuing communities are converting to dominance by other tree species (Crow 1988; Lorimer 1993; Johnson 1993). This is particularly evident on mesic sites, where oak seldom recruits into the canopy of newly forming or existing stands (e.g., Pallardy et al. 1988; Hix and Lorimer 1991; Abrams and Nowacki 1992). This fail-

Received July 31, 1996. Accepted May 1, 1997.

E.L. Kruger. ${ }^{1}$ Department of Forestry, University of Wisconsin-Madison, 120 Russell Labs, 1630 Linden Avenue, Madison, WI 53706, U.S.A.

P.B. Reich. College of Forest Resources, University of Minnesota, St. Paul, MN 55108, U.S.A.

${ }^{1}$ Author to whom all correspondence should be addressed. ure appears to result in large part from the inability of oak reproduction to survive and compete with other shade-tolerant and (or) fast-growing woody vegetation under existing forest conditions (Crow 1988; Lorimer 1993; Johnson 1993).

The current importance of Quercus in eastern North America has been linked to widespread fire prior to European settlement in the 19th century (Lorimer 1985b; Crow 1988; Abrams 1992; Johnson 1993). In light of this, and given the present oak regeneration dilemma, there is much interest in prescribed burning as a tool in oak forest reestablishment. However, the present database on fire and oak regeneration gives no clear indication as to the potential utility of burning in the restoration of mesic oak forests (Johnson 1974; McGee 1979; Merritt and Pope 1991). In 1989, this issue was addressed with a study of the impacts of successive annual fires on regeneration-stage individuals of northern red oak and competing tree species in mesic forest openings in southwestern Wisconsin. During a 2-year period, community dynamics as well as the biomass growth and ecophysiology of oak and sympatric tree species were monitored on burned and nonburned plots. The overall aim of the study was to determine 
Table 1. Characteristics of the 1989 and 1990 spring fires and fire environments.

\begin{tabular}{cccccc}
\hline & $\begin{array}{c}\text { Air } \\
\text { temp. } \\
\left({ }^{\circ} \mathrm{C}\right)\end{array}$ & $\begin{array}{c}\text { RH } \\
(\%)\end{array}$ & $\begin{array}{c}\text { Wind speed } \\
\text { and direction } \\
\left(\mathrm{m} \cdot \mathrm{s}^{-1}\right)\end{array}$ & $\begin{array}{c}\text { Flame } \\
\text { height } \\
(\mathrm{cm})\end{array}$ & $\begin{array}{c}\text { Rate of } \\
\text { spread } \\
\left(\mathrm{m} \cdot \mathrm{min}^{-1}\right)\end{array}$ \\
\hline 1989 & 19 & 34 & $2.0 \mathrm{~W}$ & 25 & 1.0 \\
1990 & 28 & 47 & $1.5 \mathrm{SW}$ & 13 & 0.8 \\
\hline
\end{tabular}

Note: Values are averages of measures taken on the four burn plots.

the influences of fire on the competitive status of northern red oak in a relatively resource-rich environment, and to identify the causes for the observed effects. The focus of the present paper is post-fire community dynamics, with particular emphasis on the survival and height growth of oak and sympatric tree species. Fire effects on the biomass growth and ecophysiology of tree regeneration are summarized in companion papers (Kruger and Reich 1997a, 1997b).

\section{Materials and methods}

\section{Study area}

The study was conducted on the Jordan Timberland, a privately owned forest located in the "Driftless" physiographic region of southwestern Wisconsin $\left(42^{\circ} 59^{\prime} \mathrm{N}, 90^{\circ} 07^{\prime} \mathrm{W}\right)$ (Braun 1950). The common landform in this region is a gently rolling upland deeply dissected by numerous watercourses. On the steep slopes of these watersheds, dolomite and sandstone are typically overlain by relatively fertile, silt loam soils derived from wind-blown loess. Prairies and oak savannas dominated much of the area prior to settlement by Europeans in the mid-1800s (Curtis 1959; Stroessner and Habek 1966). In the absence of fire, savannas have since been replaced by oak-hickory forests, which dominate much of the forested landscape today. During the last several decades, however, northern hardwood species such as sugar maple (Acer saccharum Marsh.), basswood (Tilia americana L.), and white ash (Fraxinus americana L.) have rapidly colonized mesic sites in the area (Hix and Lorimer 1991).

Southwestern Wisconsin has a humid continental climate with a 30 -year mean for annual precipitation of $810 \mathrm{~mm}$, and 30-year means for July and January temperatures of $22^{\circ} \mathrm{C}$ and $-9^{\circ} \mathrm{C}$, respectively (U.S. Department of Commerce 1990). Total precipitation during the growing season (May through October) at a weather station $7 \mathrm{~km}$ southeast of the study area was $340 \mathrm{~mm}$ in 1989 and $660 \mathrm{~mm}$ in 1990, compared with a 30-year mean of $490 \mathrm{~mm}$. Average July temperature at that station was $22^{\circ} \mathrm{C}$ in 1989 and $21^{\circ} \mathrm{C}$ in 1990 (U.S. Department of Commerce 1989, 1990).

We located study sites on relatively mesic, north-facing slopes that possessed a mature overstory (dominant tree age $>70$ years) with at least $50 \%$ canopy cover, and contained adequate regeneration densities (minimum $1000 \mathrm{stems} / \mathrm{ha}$ ) of three target species, northern red oak, sugar maple, and white ash. The overstory on these sites was a mixture of mature northern red oak and white oak (Quercus alba L.), bitternut hickory (Carya cordiformis (Wangenh.) K. Koch), shagbark hickory (Carya ovata (Mill.) K. Koch), and northern hardwoods, including sugar maple, white ash, and basswood. Part of the overstory had been commercially harvested 4 years prior to the onset of the study, resulting in variable canopy densities (50-90\% canopy cover) and a range in stand basal area of 15 to $30 \mathrm{~m}^{2} \cdot \mathrm{ha}^{-1}$. The pretreatment understory on the study sites comprised largely hophornbeam (Ostrya virginiana (Mill.) K. Koch) saplings and hardwood tree regeneration less than $1 \mathrm{~m}$ in height. Initial tree regeneration densities ranged from 50000 to 250000 individuals/ha across sites. Various shrub species, including Rubus spp., Ribes spp., Cornus spp., Viburnum spp., and prickly ash (Xanthoxylum americanum Mill.), were also present in relatively low densities $(<1000$ stems/ha). Soils on these sites were Typic
Hapludalfs (Hole 1976), with a silt cap overlying a horizon of clay or clay and dolomite residuum.

\section{Experimental design and site manipulation}

A pair of $200-\mathrm{m}^{2}$ plots was established in each of four newly created 0.5 -ha openings (blocks). One randomly chosen plot in each opening was burned and the other was left as a control, and the two were separated with a 2-m buffer. A pair of openings was located on each of two slopes, one of which had a northeast aspect and the other a northwest aspect. The overstory on each block was removed in early April 1989. On all plots, stems of trees and shrubs with diameters greater than $2.5 \mathrm{~cm}$ at breast height $(1.37 \mathrm{~m})$ were felled. Except for the largest tree boles, large woody debris from felled timber was removed from the plots.

One plot in each of the four openings was burned in early May of both 1989 and 1990. We chose to burn in the spring because our past experiences (e.g., Reich et al. 1990) indicated that, in southern Wisconsin, climate and site conditions were typically most conducive to burning for the longest period during that season. Our decision to conduct successive burns was based in large part on the opinion shared by several researchers (e.g., Nyland et al. 1982; Van Lear and Waldrop 1988) that only repeated burning would provide any lasting benefit to oak regeneration. Primary fuels for these surface fires included hardwood leaf litter and fine twigs. To minimize the heterogeneity of the burn over each plot, leaf litter was raked from nearby intact forest floors and placed in areas on plots where litter was sparse. An estimated $10-30 \%$ of the total fuel load was raked onto the plots in 1989. In 1990, the litter layer on burn plots was generally sparse prior to burning, owing to its incineration in 1989 and to a lack of subsequent overstory litter input. Therefore, an estimated $50-70 \%$ of the total fuel load was raked onto the plots in 1990, with roughly equal quantities added to burn and control plots in order to avoid any potentially confounding influence of different litter inputs.

Table 1 is a summary of fire characteristics. Burning occurred in the afternoon on clear to partly cloudy days, and fires in both years were of low intensity. Flame heights rarely exceeded $30 \mathrm{~cm}$, and rate of spread averaged $0.8-1.0 \mathrm{~m} \cdot \mathrm{min}^{-1}$. Dry mass of the forest floor on burn plots prior to the 1989 and 1990 fires (after litter addition) averaged 10.6 and $6.5 \mathrm{t} \cdot \mathrm{ha}^{-1}$, respectively. Litter moisture content was not measured in 1989, and it averaged about $20 \%$ at the time of the 1990 burn. After the 1989 fire, each block was fenced ( $2 \mathrm{~m}$ in height) to minimize herbivory by deer and other mammals. The fence consisted of four wire strands above a $2.5-\mathrm{cm}$ wire mesh extending $0.75 \mathrm{~m}$ in height from the ground.

\section{Vegetation measurements}

The density and height of tree regeneration and erect-stemmed shrubs were measured on each plot in the spring of 1989 and in the fall of 1989 and 1990. In Spring 1989, we surveyed burn plots just prior to burning, while control plots were surveyed in mid-May. With the exception of sugar maple, we tallied all individuals on a plot. Because maple was so numerous, we estimated its density using six $1-\mathrm{m}^{2}$ quadrats arbitrarily located on each plot. We measured height on a random subsample of individuals from each species on all plots.

Annual height growth was compared across species and treatments based on species $\times$ plot averages for height at the beginning (pre-burn) and end of each growing season. Net height increment was calculated as the difference between initial (pre-burn) and final growing season height, while relative height growth (RHG) was calculated with the equation $\ln$ (final height) - $\ln$ (initial pre-burn height). For oak, ash and maple, we assessed the potential influence of initial height on RHG among individuals on control plots and found no correlation $(p>0.10)$ between the two (data not shown). Height growth of tree regeneration was also measured in August 1991, after annual extension growth had ceased. At that time the initial and final growing season heights of 50-75 dominant or codominant individuals (final height $>50 \mathrm{~cm}$ ) were recorded on each plot. Stems were measured 
Fig. 1. Seasonal dynamics in leaf area index (LAI) and percent vegetation cover on burn (B) and control (C) plots in 1989 and 1990. Columns represent treatment means (with their standard errors) for total LAI and percent cover measured on a given day. LAI measures were broken down into portions represented by each of several plant growth forms. An asterisk indicates a significant treatment difference $(p \leq 0.05)$ on a particular date.

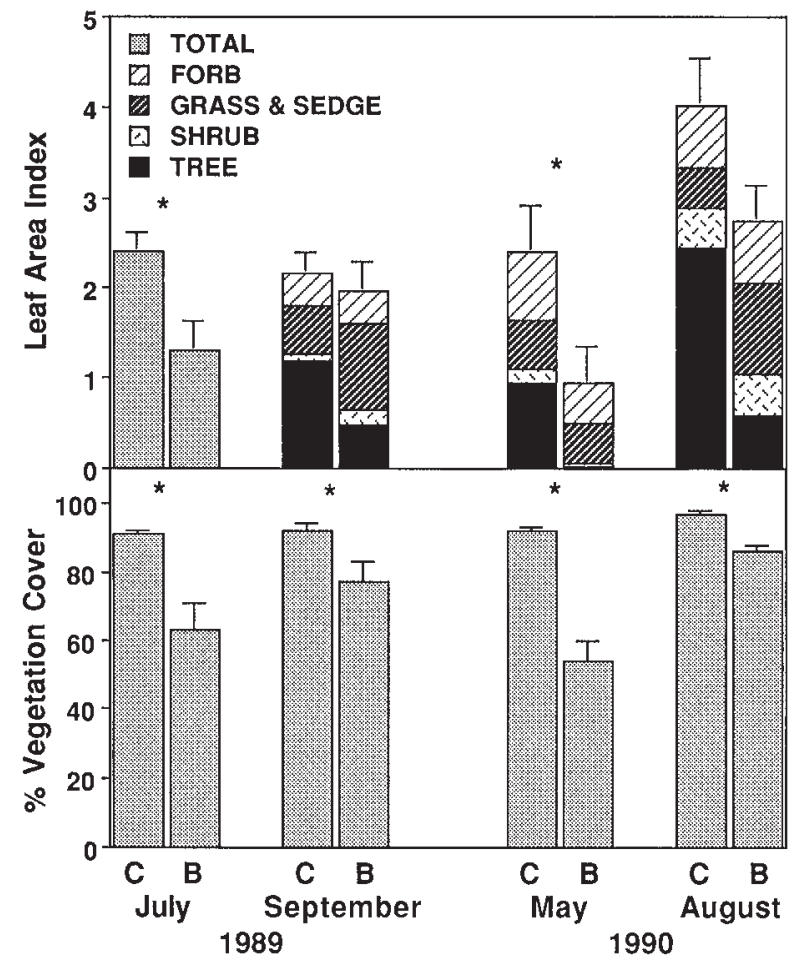

as they were encountered on arbitrary treks through the plot. An effort was made to sample all of the common tree species and to distribute the sampling evenly over the plot.

Vegetation cover and leaf area index (LAI) were estimated on all plots twice during each growing season with a drop-line method (MacArthur and Horn 1969; Miller and Lin 1985), using ca. 100 sampling points per plot. This approach allowed us to determine percent cover and LAI for each plant growth form. The probe was oriented vertically, and no effort was made to account for leaf angle distributions. Since this strategy could introduce a bias in LAI estimates, its validity was assessed on all plots in August 1990 with measures of canopy light interception using a sunfleck ceptometer (Decagon Devices, Logan, Utah, U.S.A.). Based on the Beer-Lambert equation, we determined the light extinction coefficient $(k)$, which, within each treatment, produced close agreement $( \pm 10 \%$ on all plots $)$ in LAI between the two approaches. The $k$ for burn and control plots was -0.51 and -0.55 , respectively. These values appeared to be reasonable for mixed woody broadleaf and herbaceous vegetation (Norman and Campbell 1989; Russell et al. 1989; Vose et al. 1995), and the treatment difference in $k$ was consistent with fire effects on the relative abundance of different plant growth forms (Figs. 1 and 2).

\section{Statistical analysis}

The effects of treatment, species, and their interaction were examined with analysis of variance (ANOVA) using the general linear models procedure (PROC GLM) in SAS (SAS Institute Inc. 1988). The study was set up as a split-plot design in a randomized complete block arrangement, treating plots as whole units and species as subunits. When the effect of blocking was not significant $(p>0.10)$ the data were analyzed as if the split plot was in a completely randomized
Fig. 2. Comparative dynamics in vegetation cover and leaf area index (LAI), broken down by plant growth form, on burned and control plots: (A) percent cover measured in August 1990; (B) changes in percent cover between September 1989 and August 1990; and (C) changes in LAI between September 1989 and August 1990. Columns represent treatment means (with their standard errors). Fisher's least significant differences (LSD, $p=$ $0.05)$ are provided for comparing means within $\left(\mathrm{LSD}_{\mathrm{WT}}\right)$ and across $\left(\mathrm{LSD}_{\mathrm{AT}}\right)$ treatments.

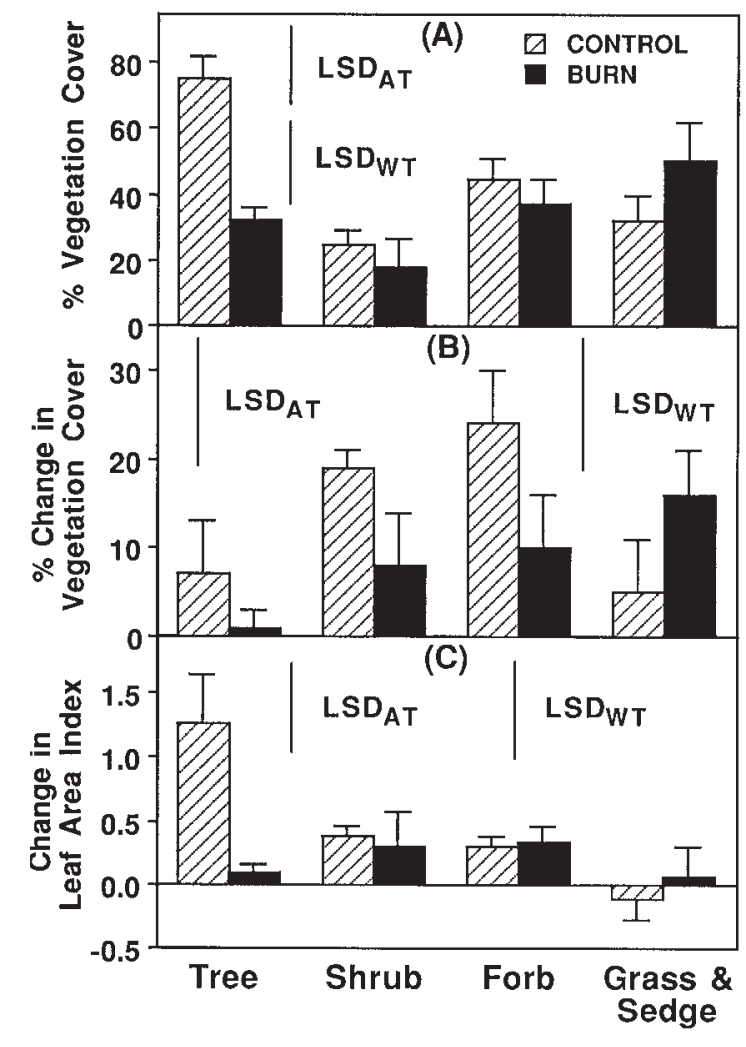

arrangement. In tests involving repeated measures (either at the plot or species level), a split-plot analysis was used, treating either plot or species as a whole unit and year as the subunit. Relationships among continuous variables were analyzed with linear regression (PROC GLM). ANOVAs and regressions were significant if $p \leq 0.05$.

Homogeneity of variance was tested with Levene's method (Milliken and Johnson 1989); when heteroscedasticity was found, the data were transformed (e.g., with natural logarithm) prior to ANOVA. Fisher's protected LSD was used to identify significant differences among means. In accordance with the split-plot design, different LSDs were calculated for mean comparisons within and across treatments. The derivation of within-treatment LSDs was based on subunit error, while across-treatment LSDs were calculated based on a combination of subunit and whole-unit error (Milliken and Johnson 1989). When appropriate, percentage data were arcsine-transformed prior to ANOVA.

\section{Results}

Although the surface fires in both 1989 and 1990 were of low intensity, they were sufficiently uniform and intense to top-kill virtually all woody vegetation on burn plots. Basal sprouts began to appear on woody survivors 10 to 20 days after each fire. Burning inhibited the development of total vegetation cover and LAI, although both tended to recover on burn plots 
Table 2. Initial (pre-burn) regeneration densities and stem heights of the most common tree species on the study plots in 1989 .

\begin{tabular}{lcc}
\hline & $\begin{array}{c}\text { Initial density } \\
\text { (individuals/ha) }\end{array}$ & $\begin{array}{c}\text { Initial height } \\
(\mathrm{cm})\end{array}$ \\
\hline Sugar maple & $150000(28900)$ & $24(3)$ \\
Red oak & $4300(1300)$ & $24(2)$ \\
Bitternut hickory & $1800(900)$ & $38(4)$ \\
Hophornbeam & $1800(300)$ & $47(6)$ \\
White ash & $1400(600)$ & $42(5)$ \\
Black cherry & $600(100)$ & $33(6)$ \\
\hline
\end{tabular}

Note: For a given species, neither density nor height differed

significantly between burn and control plots. Values are means (with their standard deviations) based on all plots $(n=8)$

with respect to controls as each growing season progressed (Fig. 1). Burning had a differential influence on the abundance of plant growth forms. Fire substantially decreased the percent cover and LAI of tree regeneration, whereas it tended to stimulate the growth of grasses and sedges (Figs. 1 and 2). As a whole, shrubs and forbs were least affected by burning.

Total density of tree regeneration, which initially averaged over 160000 individuals/ha (Table 2), decreased on burn plots by $85 \%$ after the two fires, with a $75 \%$ drop in 1989 and an additional $10 \%$ decrease, relative to original values, in 1990 . Total regeneration densities on control plots did not change significantly during the study. Fire effects on density varied widely among tree species (Fig. 3). Of the most common species on the sites prior to treatment, sugar maple, hophornbeam, and white ash suffered the highest percent mortality on burn plots. Bitternut hickory was unaffected by fire, while the density of red oak increased after the first burn and remained the same thereafter. In relative terms, the negative impact of the 1989 burn was larger than that in 1990 for ash and maple. Maple regeneration densities decreased by $80 \%$ after the 1989 fire, while $50 \%$ of the 1989 survivors failed to resprout after the 1990 fire. In contrast, the largest proportional decline in hophornbeam density was observed after the 1990 burn.

Fire also affected the demographics of less common trees species. For example, the density of slippery elm (Ulmus rubra Müh1.) increased on all plots over the 2-year study, but gains were significantly less on burn plots than on controls (data not shown). By the fall of 1990, elm density, which initially averaged fewer than 100 individuals/ha across all plots, reached 800 individuals/ha on control plots but only 380 individuals/ha on burn plots. Other than the case of elm, tree species densities did not change significantly on control plots, and correspondingly, we observed little evidence of seedling recruitment or mortality in the absence of fire. On burn plots, we noticed a few red oak germinants from acorns that survived the fire in 1989.

Densities of certain shrub species also decreased after fire (Fig. 4). In 1989, stem densities of prickly ash changed little on control plots, whereas they decreased by about $40 \%$ on burn plots. In 1990, however, prickly ash densities on burn plots increased to levels that exceeded 1989 pre-burn values, and treatment differences disappeared. On the other hand, less than $50 \%$ of the dogwoods (Cornus spp.) resprouted after the 1989 fire, and densities decreased to about $10 \%$ of original levels after burning in 1990. For shrub and tree species, mortality
Fig. 3. Relative post-fire densities of the six most common tree species on the study plots. Columns represent the mean burn plot density, expressed as a percentage of 1989 preburn density, measured after the 1989 and 1990 spring fires. Fisher's least significant differences (LSD, $p=0.05$ ) are provided for comparing means within $\left(\mathrm{LSD}_{\mathrm{WS}}\right)$ and across $\left(\mathrm{LSD}_{\mathrm{AS}}\right)$ species.

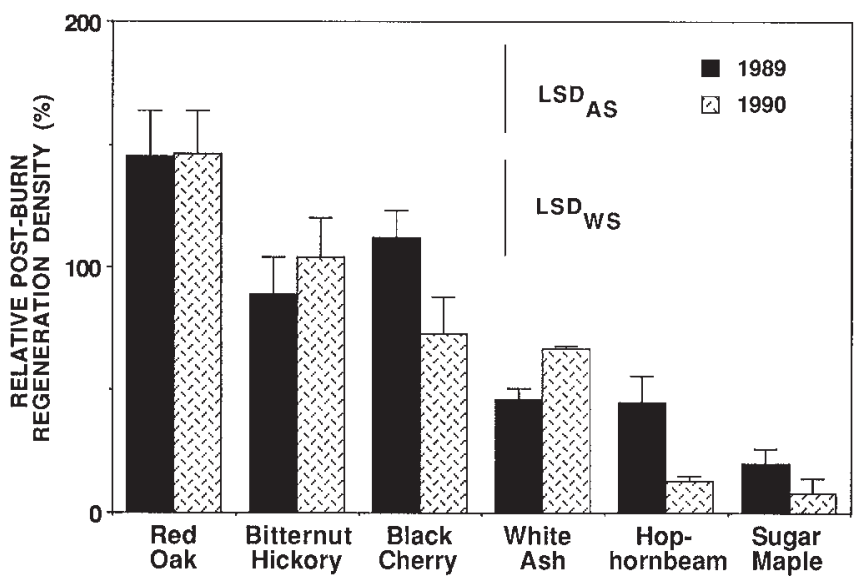

frequently appeared to result from the inability of individuals to sprout from living tissues at or below the soil surface following top kill. This was manifested by the maintenance of a living periderm below the stem girdle on nonsprouting plants, and continued secondary growth of the stem or root just below that point. There was also limited evidence that smaller trees failed to resprout more frequently than larger ones after fire. Although the disappearance of dead stems largely precluded measurement of the original pre-burn height of fire survivors, a few measures (fewer than 10 individuals per species per plot) were obtained each year. Based on these data, the average initial (pre-burn) heights of surviving white ash and sugar maple were $3-5 \mathrm{~cm}$ greater than corresponding averages for the respective pre-burn populations in 1989. However, neither of these differences was significant, and they were not evident in 1990.

Burning suppressed net height growth of tree regeneration in 1989 but generally had less effect in 1990 (Fig. 5). In 1989, height growth of maple, ash, and hophornbeam was most negatively affected by fire, followed by that of black cherry (Prunus serotina Ehrh.) and hickory. Red oak was the only species to post a net gain (with respect to pre-burn height) on burn plots in 1989. The effect of fire on net growth occurred despite the fact that total height growth of post-fire sprouts more than doubled that of control stems on average. For example, the total height gain of post-fire oak sprouts in 1989 averaged $28 \mathrm{~cm}$ compared with $11 \mathrm{~cm}$ for stems on control plots (data not shown). Across both treatments, height growth of all tree species was greater in 1990 than in 1989. With the exception of hophornbeam, post-fire height growth in 1990 exceeded initial losses on burn plots, and for ash, oak, and hickory, net height increments did not differ significantly between treatments in that year. Net 1990 growth by hophornbeam and cherry was $60-100 \%$ less $(p<0.05)$ on burn plots than on controls. Cumulative net height increment during 1989 and 1990 was at least $65 \%$ less on burn plots than on controls for all of the common tree species except hickory and oak (Fig. 6). Two-year height gains for hickory and oak decreased 
Fig. 4. Dynamics in the density of common shrub species. Columns represent the mean stem density, expressed as a percentage of spring 1989 (pre-burn) density, on burn and control plots in the fall of 1989 and 1990. See Fig. 2 for legend. Fisher's least significant differences (LSD, $p=$ $0.05)$ are provided for comparing means within $\left(\mathrm{LSD}_{\mathrm{WT}}\right)$ and across $\left(\mathrm{LSD}_{\mathrm{AT}}\right)$ treatments.

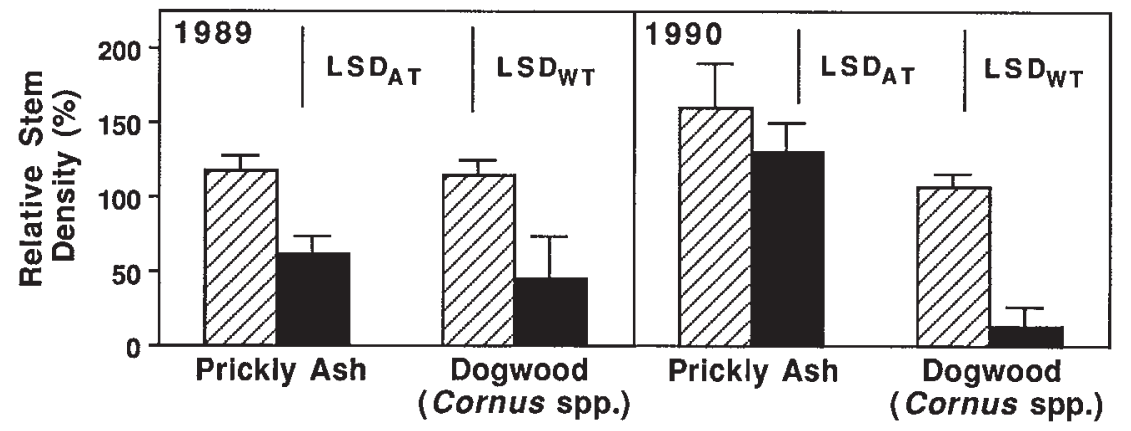

Fig. 5. Net height increment (with respect to pre-burn height) by regeneration of the six most common tree species on burn and control plots in 1989 and 1990. See Fig. 2 for legend. Fisher's least significant differences (LSD, $p=0.05)$ are provided for comparing means within $\left(\mathrm{LSD}_{\mathrm{WT}}\right)$ and across $\left(\mathrm{LSD}_{\mathrm{AT}}\right)$ treatments.

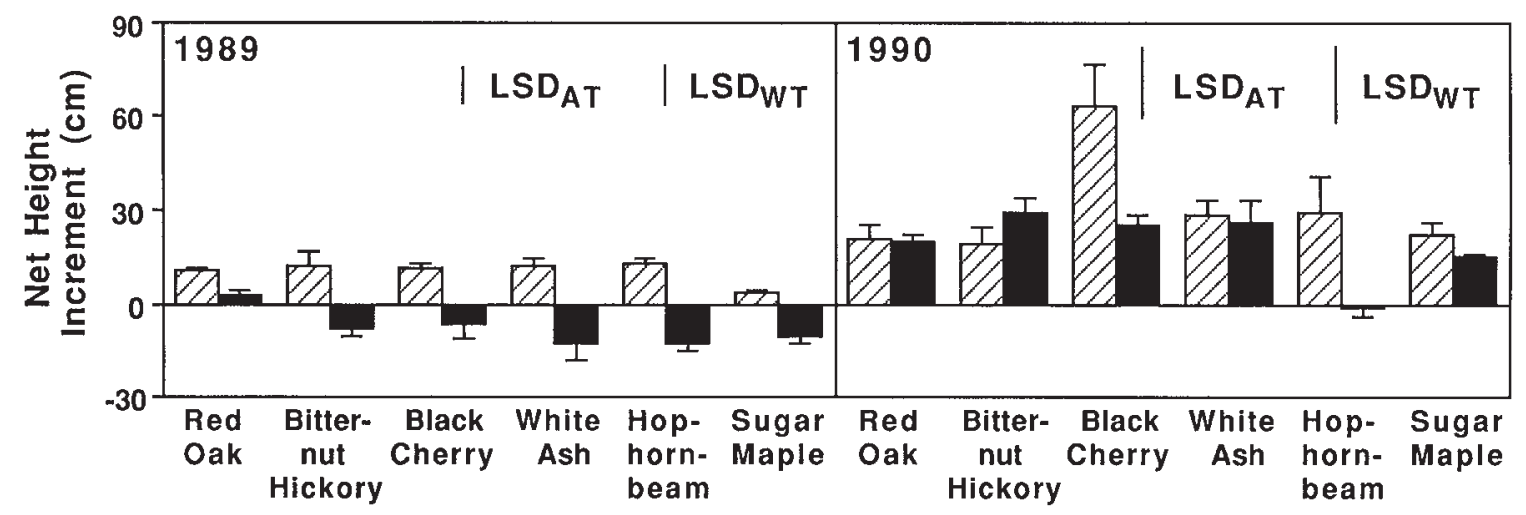

about $30 \%$ on burn plots, although these losses were not significant. Fire impacts on relative height growth (RHG) were similar to those on absolute height growth during the 2-year period. As a result, cumulative RHG of red oak was the greatest $(p<0.05)$ among tree species on burn plots, and more than doubled that of maple, ash, and hophornbeam.

Post-fire changes in population structure may have been associated in part with fire-induced changes in plant growth rate. In 1989 and 1990, the percent change in regeneration density after fire was significantly and positively correlated with the percent difference in height growth between post-fire survivors and nonburned individuals (Fig. 7). This was true in both years despite changes in species rankings in growth and density. In terms of height growth and density, oak responded most positively and maple most negatively to fire in 1989. In 1990, ash-hickory and hophornbeam represented the positive and negative extremes in this relationship. Regression slopes did not differ $(p>0.10)$, but there was a significant difference in intercept.

With the exception of cherry, oak kept pace with the other tree species in terms of average height growth on control plots in 1989 and 1990 (Figs. 5 and 6). However, when we compared the distribution of oak and maple densities among RHG classes on control plots in 1990, maple density overwhelmed that of oak in every RHG class (data not shown). For example, each oak with an RHG greater than 0.9 was accompanied by 17 maples with equivalent or higher growth rates. In an effort to visualize and compare temporal dynamics in the competi- tive status of oak relative to other woody vegetation in each treatment, we charted the distribution of woody plant density among height classes at three key points in time during the study (Fig. 8). Prior to burning in Spring 1989, oak represented less than $3 \%$ of all tree regeneration, and less than $1 \%$ of the tallest 3000 individuals/ha, on both control and burn plots. This condition remained unchanged on control plots. In contrast, oak represented more than $16 \%$ of all tree regeneration, and $18 \%$ of the tallest 3000 individuals/ha, on burn plots in the fall of 1990. However, in 1991 dominant and codominant individuals of all species grew rapidly in both treatments (Fig. 6). In the absence of fire, neither absolute nor relative height growth differed significantly between treatments for any species, and the growth advantage that oak experienced on burn plots during the 2-year fire regimen all but disappeared.

\section{Discussion}

Consecutive spring fires markedly altered the floristic composition of newly created openings in mesic hardwood stands. The severe impact of fire on tree regeneration as a whole was in large part a consequence of the fire sensitivity and overwhelming initial density of young sugar maple. In the absence of maple, however, tree density would still have declined appreciably, as several other species were also adversely affected by repeated burning. In general, the effects of fire on different plant growth forms in this study were consistent with past observations. The low-intensity fires that typically occur in 
Fig. 6. Net height growth (with respect to 1989 pre-burn height), in absolute and relative terms, by regeneration of the six most common tree species on burn and control plots during the 2-year fire regimen $(1989+1990)$, as compared with growth of dominant and codominant individuals in 1991. See Fig. 2 for legend. Fisher's least significant differences (LSD, $p=0.05$ ) are provided for comparing means within $\left(\mathrm{LSD}_{\mathrm{WT}}\right)$ and across $\left(\mathrm{LSD}_{\mathrm{AT}}\right)$ treatments.

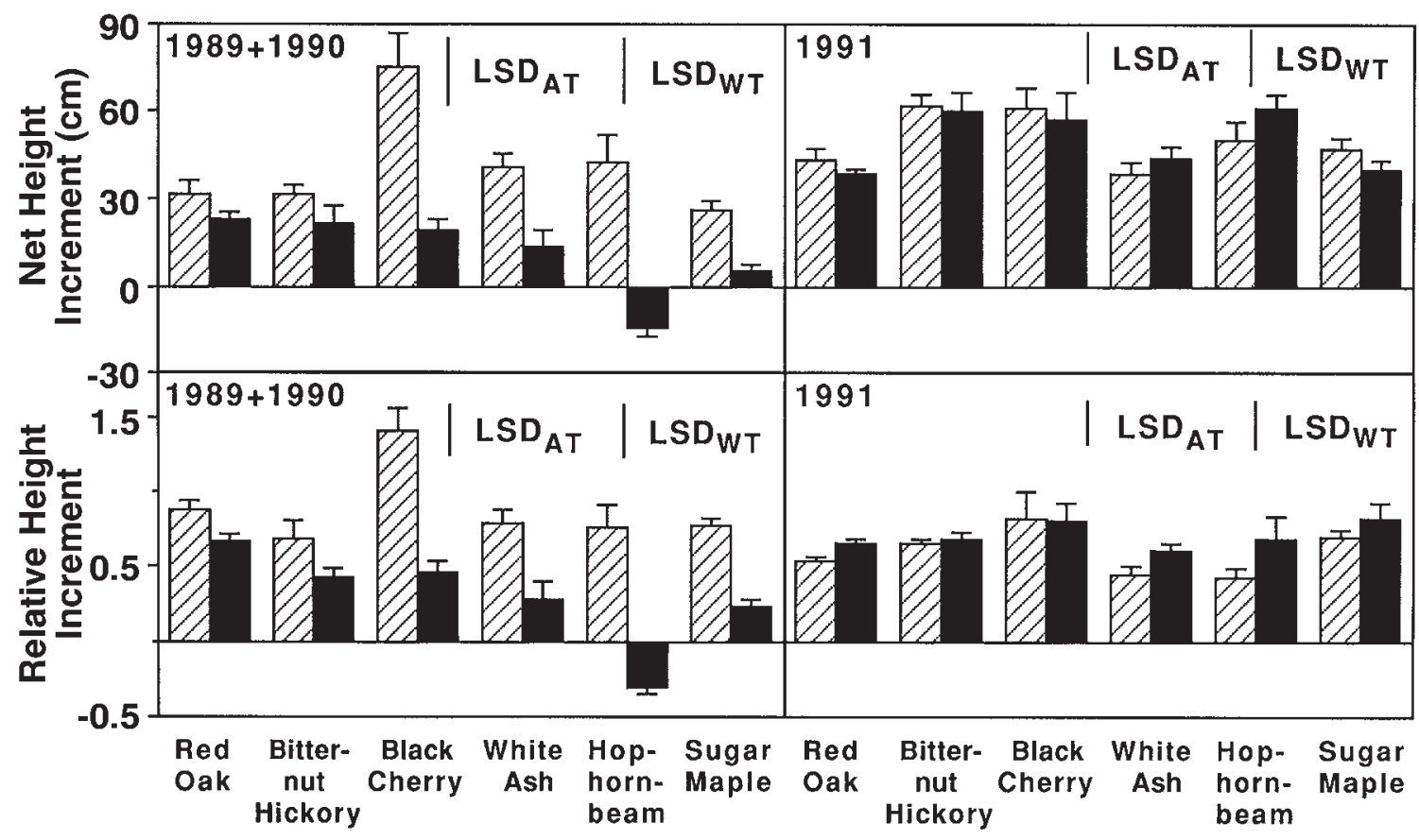

mesic forests rarely harm larger trees, but they often cause a marked shift in the composition of young hardwood stands and forest understories (Brown 1960; Swan 1970; Nyland et al. 1982). For example, Swan (1970) found that tree regeneration was much less common in spring-burned than in nonburned oak and northern hardwood stands, while the opposite was true for grass and sedge species.

Past fire research also corroborates the relative fire sensitivities exhibited by different tree species in this study. Decreases in the density or frequency of young sugar maple, hophornbeam, and white ash have been observed following fires of varying intensities (Brown 1960; Swan 1970). Young sugar maple appears to be especially vulnerable to fire. For instance, Anderson (1983) found that as much as $90 \%$ of the sugar maple seedlings and saplings in a northern hardwood forest understory were killed by a single low-intensity fire. On the other hand, the reputed fire tolerance of oak and hickory seedlings (Brown 1960; Swan 1970; McGee 1979; Reich et al. 1990) was reaffirmed here. It appeared that a major cause of fire-induced mortality among sensitive shrubs and trees was an inability to sprout from surviving belowground tissues. If some of oak's woody competitors frequently die and (or) grow more slowly than oak as a result of top kill alone, methods such as coppicing vegetation near the soil surface may be useful surrogates to fire in controlling competition. Stem removal at the soil surface has been shown to kill a high proportion of certain hardwood species, such as hophornbeam (Diller and Marshall 1937), presumably because of a lack of dormant or adventitious buds below ground. Although most tree species in our study are known to resprout readily after coppicing (e.g., Averell 1929), there is little information regarding the responses of individual species to girdling at or below the soil surface.
We cannot explain with certainty the apparent increase in oak density after the 1989 fire. Survival and germination of acorns and early establishment of oak seedlings may be enhanced by fire. In experiments with planted acorns in both mesic and xeric oak woodlands in Minnesota, acorn predation was less and germination and early seedling survival were greater for several oak species on burned as opposed to nonburned plots (P.B. Reich et al., unpublished data). Alternatively (or complementary), if recruitment was roughly equal to mortality in a given year, a decrease in competition-induced oak mortality could lead to increased oak density, either with or without a change in recruitment. Yet recruitment is not likely to be similar from year to year, and in the absence of fire there was little oak mortality observed during the present study. We also suspect that the increase in oak numbers on burn plots in 1989 may have been, at least in part, an artifact of the woody survey regimen. Shoot dieback is common for oak seedlings in understories, and some oaks on all plots probably lacked a living terminal prior to burning in Spring 1989. Many of these individuals, which were largely dormant when burn plots were surveyed, may have resprouted from basal buds before surveys were conducted on control plots 1 to 2 weeks after the burn. Thus, some previously unnoticed individuals may have been tallied on burn plot surveys in fall 1989, whereas the situation was averted on controls. In any case, data from previous (Reich et al. 1990) and subsequent fire research (E.L. Kruger et al., unpublished data) indicate that low-intensity surface fires cause little mortality in young oaks.

Sparingly little information exists regarding the comparative growth of hardwood species after fire on mesic sites. In this study, oak growth was least affected by fire, and consequently it gained the most height, in both absolute and relative 
Fig. 7. Relationships between the percent change in regeneration density (with respect to pre-burn density) on burn plots and the relative difference in net height growth between burn and control plots in 1989 and 1990. Species means were used as individual data for these regressions. For 1989, \% change in density $=63.6+$ $0.47\left(\%\right.$ difference in height growth), $r^{2}=0.79, p=0.01$; for 1990 , $\%$ change in density $=-0.3+0.66(\%$ difference in height growth $)$, $r^{2}=0.56, p=0.05$. The relationships differed in intercept $(p \leq 0.05)$ but not in slope. Species are identified using the initials of their common names.

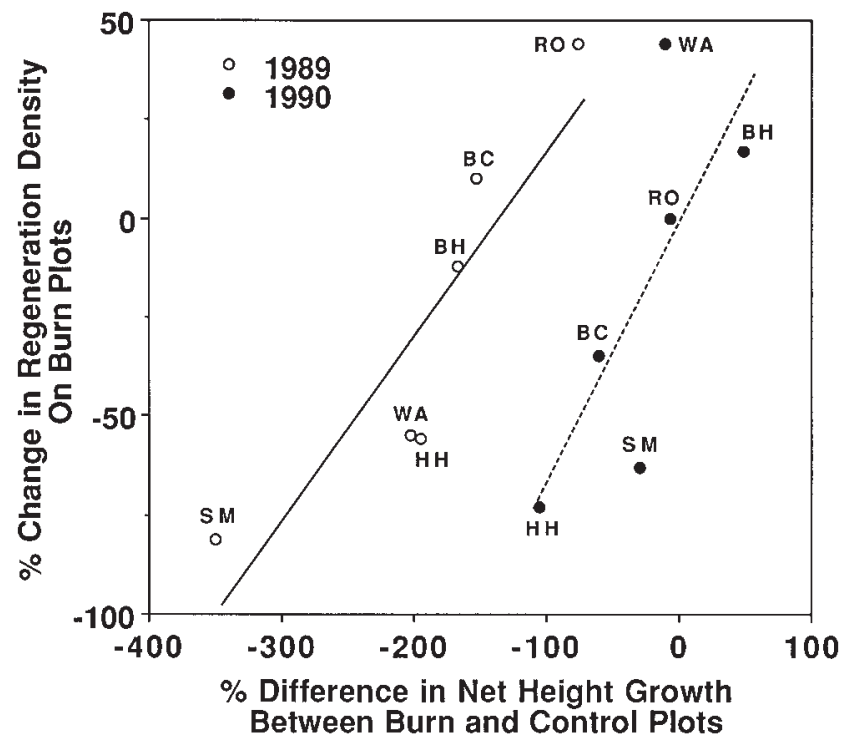

terms, of any species on burn plots during the 2-year treatment. Although net height growth of most species was decreased substantially by fire, the total height growth of post-fire sprouts was generally greater than that of intact stems on control plots. This was consistent with previous findings on the response of hardwood seedlings to fire or top kill (Johnson 1974; Kruger and Reich 1993). Kruger and Reich (1993) found that total height growth by coppiced oak seedlings was twice that of noncoppiced controls, and this difference was associated with an increased allocation to height growth of mass that would otherwise have been usurped by secondary growth of the original intact stem. However, as in the case of the coppiced seedlings, rapid height growth by post-fire sprouts in the present study did not fully compensate for the height lost from repeated stem destruction on burn plots.

The impacts of the first fire (1989) on tree regeneration as a whole were more pronounced than those of a second fire 1 year later. Losses in regeneration density and relative decreases in net height growth were most severe in 1989. Mortality may have been proportionally less for fire-sensitive species in 1990 because the most vulnerable individuals had disappeared in 1989. Year-to-year differences in growth effects may have resulted in large part from the timing of fire in relation to environmental factors. The minimal recovery of height on burn plots in 1989 coincided with relatively slow height growth on control plots in that year, while stem growth was vigorous on all plots in 1990. Slow growth in 1989 may have been a consequence of a region-wide drought in 1988 and early 1989. There were physiological indications of at least moderate water stress on the study plots early in 1989 (Kruger and Reich 1997a). Alternatively, a lag in the growth response of understory vegetation has often been observed following overstory removal (e.g., Lorimer 1985a).

In the absence of fire, the fate of oak was by no means certain at the end of 3 years of monitoring. While average height growth was similar among most species in 1989 and 1990 , even the fastest growing oaks were greatly outnumbered by maples and other competitors growing as or more rapidly. The marginal competitive status of red oak was consistent with the general observation that oak often fails to maintain a dominant or codominant position in the newly forming canopy of mesic forest openings (e.g., McGee 1979; Johnson 1976; Parker and Sherwood 1987). This in turn is associated with its typically slow rate of biomass growth in resource-rich environments (Farmer 1980; Walters et al. 1993; Kruger and Reich $1997 b$ ). In contrast with the situation on control plots, oak outgrew maple on burn plots during the 2-year burning regimen, and this reversal was linked to the differential effects of fire on key growth determinants such as leaf photosynthesis and leaf weight ratio (Kruger and Reich 1997a, 1997b). Indeed, the effects of fire on population densities as well as growth may have been at least partially mediated by these physiological impacts. The observed correlation between changes in population densities and post-fire growth decreases on burn plots provided an indication, albeit indirect, of this possible causal linkage. Such a pattern is also consistent with a strong association between survival and the maintenance of a positive seedling carbon balance in red oak, sugar maple, hophornbeam, and other species when grown under stressful conditions (low light) (Walters and Reich 1996).

The cumulative influences of burning on the competitive status of oak were perhaps most evident in the temporal dynamics of species distributions among height classes. In the absence of fire, oak remained unrepresented in the tallest classes and was generally inundated by woody competitors at all heights throughout the course of the study. On the other hand, because fire negatively impacted its chief competitors with respect to overall density and recruitment of individuals into taller classes, oak composed a larger proportion of most height classes, and especially the tallest ones, on burn plots than it did on controls. Given the short-term nature of this study, however, it was uncertain as to whether oak would maintain a competitive advantage on burn plots in the long run, as treatment influences on height growth virtually disappeared during the first growing season without fire, and oak was once again one of the slower growing species on burn as well as control plots.

Our findings may be encouraging for those interested in the reestablishment of oak on mesic sites in eastern North America. Several factors must be considered, however. The first is the feasibility of burning in mesic forests. Fuel loads at the time of the first burn were sufficient to lightly burn a large forest area, allowing for the existence of scattered nonburned patches. Although we added fuel (litter), this was for experimental purposes and would not be necessary (or feasible) for applied objectives. Fuel loads in our openings 1 year after the first burn were insufficient to carry a large fire. However, burning in successive years was an experimental protocol, and we believe that burning every 3 to 6 years would be a more feasible and effective approach, in terms of both adequacy of fuel load and likely impact on oak and competing woody regeneration. 
Fig. 8. Temporal dynamics in the density distribution of oak versus all other tree regeneration among stem height classes on burn and control plots. Data are treatment means, based on four plot densities for each height class. Graphs are based on vegetation surveys taken at the times indicated.

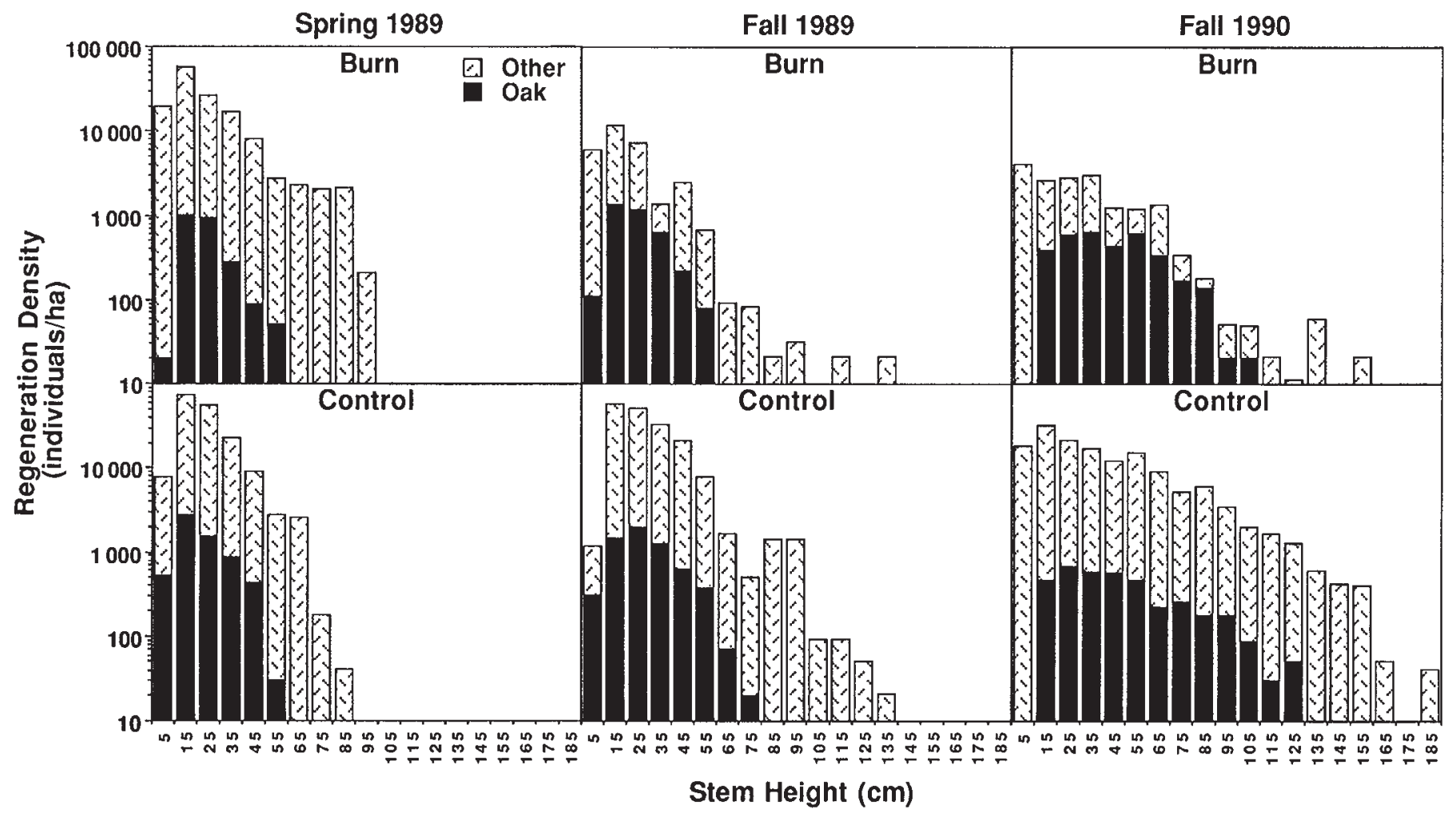

Similar recommendations have been made by others (e.g., Nyland et al. 1982), although much uncertainty exists regarding the number of burns, along with their spacing in time, that may be required to enable a sufficient number of oaks to become established and to eventually achieve canopy codominance.

We also emphasize that the scope of inference in this study should be confined to sites in which the overstory and larger undergrowth have been removed, as fire may have very different effects on tree survival and growth in forest understories, and in openings where larger, less fire-sensitive sapling- and pole-sized trees are abundant. A third factor coloring the interpretation of our data is that this study was conducted with a minimal influence of deer and other mammal herbivory. Populations of deer are generally high in eastern North America, and their browsing can greatly alter the structure and composition of hardwood and conifer forests (Marquis 1974; Frelich and Lorimer 1985; Trumbull et al. 1989). The impact of deer on oak regeneration must be characterized more thoroughly in conjunction with potential management techniques such as prescribed burning.

The results of this experiment are consistent with historical evidence and previous case studies regarding fire and oak in eastern North America (Abrams 1992; Johnson 1993). It seems likely that presettlement fires played a key role in the maintenance of open grass- and sedge-dominated communities on mesic as well as xeric sites. Fire-sensitive species, such as sugar maple, were excluded from such sites, while oaks and other fire-adapted species persisted as resprouting "grubs" that subsequently dominated much of the landscape of southwestern Wisconsin after fire suppression (Curtis 1959). Based on the present study, fire appears to enhance the competitive status of northern red oak in mesic forest openings by (1) lowering the density of key woody competitors and (2) improving the growth rate of oak relative to other woody survivors. Results also indicate that while a single low-intensity fire may provide some benefit to oak on mesic sites, the effects of fire are ephemeral, and repeated burning is necessary to hold the growth of oak's competitors in check.

\section{Acknowledgments}

We are very grateful to Rachel and Don Jordan for letting us conduct this project in the Jordan Timberland, and for their continuing support of oak ecology research. Financial support was provided by the Elmer G. Biddick Foundation, The Nature Conservancy, The University of Wisconsin-Madison, and the USDA Competitive Grants Program (CRGO-USDA 9037290-5686). We also thank John Bliss, David Ellsworth, Ron Gropp, John Volin, Dirk Vanderklein, Mike Walters, and Beth Wertschnig for their assistance in various aspects of the study. We are particularly indebted to Brian Kloeppel for his invaluable help throughout the project.

\section{References}

Abrams, M.D. 1992. Fire and the development of oak forests. BioScience, 42: 346-353.

Abrams, M.D., and Nowacki, G.J. 1992. Historical variation in fire, oak recruitment, and post-logging accelerated succession in central Pennsylvania. Bull. Torrey Bot. Club, 119: 19-28. 
Anderson, H.W. 1983. Regenerating yellow birch with prescribed fire. In Proceedings, America's Hardwood Forests-Opportunities Unlimited, 1982 Convention of The Society of American Foresters, 19-22 Sept., Cincinnati, Ohio. Society of American Foresters, Washington, D.C. pp. 168-172.

Averell, J.L. 1929. Factors affecting the reproduction of hardwood forests in southern Connecticut. J. For. 27: 55-61.

Braun, E.L. 1950. Deciduous forests of eastern North America. MacMillan Publishing Company, New York.

Brown, J.H. 1960. The role of fire in altering the species composition of forests in Rhode Island. Ecology, 41: 310-316.

Crow, T.R. 1988. Reproductive mode and mechanisms for selfreplacement of northern red oak (Quercus rubra) — a review. For. Sci. 34: 19-40.

Curtis, J.T. 1959. The vegetation of Wisconsin. University of Wisconsin Press, Madison.

Diller, O.D., and Marshall, E.D. 1937. The relation of stump height to the sprouting of Ostrya virginiana in northern Indiana. J. For. 35: 1116-1119.

Farmer, R.E. 1980. Comparative analysis of 1st year growth in six deciduous tree species. Can. J. For. Res. 10: 35-41.

Frelich, L.E., and Lorimer, C.G. 1985. Current and predicted longterm effects of deer browsing in hemlock forests in Michigan, USA. Biol. Conserv. 34: 99-120.

Hix, D.M., and Lorimer, C.G. 1991. Early stand development on former oak sites insouthwestern Wisconsin. For. Ecol. Manag. 42: 169-193.

Hole, F.D. 1976. Soils of Wisconsin. University of Wisconsin Press, Madison.

Johnson, P.S. 1974. Survival and growth of northern red oak seedlings following a prescribed burn. USDA For. Serv. Res. Note NC-177.

Johnson, P.S. 1976. Eight-year performance of interplanted hardwoods in southern Wisconsin oak clearcuts. USDA For. Serv. Res. Pap. NC-126.

Johnson, P.S. 1993. Perspectives on the ecology and silviculture of oak-dominated forests in the central and eastern states. USDA For. Serv. Gen. Tech Rep. NC-153.

Kruger, E.L., and Reich, P.B. 1993. Coppicing affects growth, root:shoot relations and ecophysiology of potted Quercus rubra seedlings. Physiol. Plant. 89: 751-760.

Kruger, E.L., and Reich, P.B. 1997a. Responses of hardwood regeneration to fire in mesic forest openings. II. Leaf gas exchange, nitrogen concentration, and water status. Can. J. For. Res. 27: 1832-1840.

Kruger, E.L., and Reich, P.B. 1997b. Responses of hardwood regeneration to fire in mesic forest openings. III. Whole-plant growth, biomass distribution, and nitrogen and carbohydrate relations. Can. J. For. Res. 27: 1841-1850.

Lorimer, C.G. 1985a. Methodological considerations in the analysis of forest disturbance history. Can. J. For. Res. 15: 200-213.

Lorimer, C.G. 1985b. The role of fire in the perpetuation of oak forests. In Proceedings, Challenges in Oak Management and Utilization. Cooperative Extension Service, University of Wisconsin, Madison. pp. 8-25.

Lorimer, C.G. 1993. Causes of the oak regeneration problem. In Oak regeneration: serious problems, practical recommendations. USDA For. Serv. Gen. Tech. Rep. SE-84. pp. 14-39.

MacArthur, R.H., and Horn, H.S. 1969. Foliage profile by vertical measurements. Ecology, 50: 802-804.

Marquis, D.A. 1974. The impact of deer browsing on Allegheny hardwood regeneration. USDA For. Serv. Res. Pap. NE-308.

McGee, C.E. 1979. Fire and other factors related to oak regeneration. In Proceedings, Regenerating Oaks in Upland Forests, John S. Wright Forestry Conference, 3-5 Feb. Purdue University, West Lafayette, Ind. pp. 75-81.

Merritt, C., and Pope, P.E. 1991. The effect of environmental factors, including wildfire and prescribed burning, on the regeneration of oaks in Indiana. Purdue University, West Lafayette, Ind. Agric. Exp. Stn. Bull. 612.

Miller, D.H., and Lin, J.D. 1985. Canopy architecture and a red maple edge stand measured by a point-drop method. In The forestatmosphere interaction. Edited by B.A. Hutchison and B.B. Hicks. Reidel, Boston, Mass. pp. 17-24.

Milliken, G.A., and Johnson, D.E. 1989. Analysis of messy data. Chapman and Hall, New York.

Norman, J.M., and Campbell, G.C. 1989. Canopy structure. In Plant physiological ecology: field methods and instrumentation. Edited by R.W. Pearcy, J. Ehleringer, H.A. Mooney, and P.W. Rundel. Chapman and Hall, New York. pp. 301-325.

Nyland, R.D., Abrahamson, L.P., and Adams, K.B. 1982. Use of prescribed fire for regenerating red and white oak in New York. In Proceedings of the 1982 Society of American Foresters Conference, Sept. 1982, Cincinnati, Ohio. Society of American Foresters, Washington, D.C. pp. 163-167.

Pallardy, S.G., Nigh, T.A., and Garrett, H.E. 1988. Changes in forest composition in central Missouri: 1968-1982. Am. Midl. Nat. 120: $380-390$.

Parker, G.R., and Sherwood, P.T. 1987. Hardwood regenerative response to clearcutting and edge effects in an oak dominated forest of central Indiana. In Proceedings of the Sixth Central Hardwood Conference, 24-26 Feb. 1987, Knoxville, Tenn. Edited by R.L. Hay, F.W. Woods, and H. DeSelm. University of Tennessee, Knoxville. pp. 127-138.

Reich, P.B., Abrams, M.D., Ellsworth, D.S., Kruger, E.L., and Tabone, T.J. 1990. Fire affects ecophysiology and community dynamics of central Wisconsin oak forest regeneration. Ecology, 71: 2179-2190.

Russell, G., Marshall, B., and Jarvis, P.G. 1989. Plant canopies: their growth, form and function. Cambridge University Press, Cambridge, England.

SAS Institute Inc. 1988. SAS/STAT user's guide: Release 6.03 edition, SAS Institute Inc., Cary, N.C.

Spencer, J.S., and Kingsley, N.P. 1991. The oak resource in the upper midwest: an overview. In The oak resource in the upper midwest: implications for management conference. Edited by S.B. Laursen and J.F. DeBoe. Minnesota Extension Service, University of Minnesota, St. Paul, Minn. pp. 11-17.

Stephens, G.R., and Ward, J.S. 1992. Sixty years of natural change in unmanaged mixed hardwood forests. Conn. Agric. Exp. Stn. New Haven. Bull. 902.

Stroessner, W.J., and Habek, J.R. 1966. The presettlement vegetation of Iowa County, Wisconsin. Trans. Wis. Acad. Sci. Arts Lett. 55: $167-180$.

Swan, F.R., Jr. 1970. Post-fire response of four plant communities in south central New York State. Ecology, 51: 1074-1082.

Trumbull, L.V., Zielinski, E.J., and Aharrah, E.C. 1989. The impact of deer browsing on the Allegheny forest type. North. J. Appl. For. 6: $162-165$.

United States Department of Commerce. 1989. Climatological data, Wisconsin. National Oceanic and Atmospheric Administration, Asheville, N.C. Bull. 94.

United States Department of Commerce. 1990. Climatological data, Wisconsin. National Oceanic and Atmospheric Administration, Asheville, N.C. Bull. 95.

Van Lear, D.H., and Waldrop, T.A. 1988. Effects of fire on natural regeneration in the Appalachian Mountains. In Proceedings, Guidelines for Regenerating Natural Hardwood Stands, 24-26 May 1988, Morgantown, W.Va. Edited by H.C. Smith, A.W. Perkey, and E.W. Kidd, Jr. Publ. 88-03. Society of American Foresters, Bethesda, Md. pp. 56-68.

Vose, J.M., Sullivan, N.H., Clinton, B.D., and Bolstad, P.V. 1995. Vertical leaf area distribution, light transmittance, and application of the Beer-Lambert Law in four mature hardwood stands in the southern Appalachians. Can. J. For. Res. 25: 1036-1043. 
Walters, M.B., and Reich, P.B. 1996. Are shade tolerance, survival, and growth linked? Low light and nitrogen effects on hardwood seedlings. Ecology, 77: 841-853.

Walters, M.B., Kruger, E.L., and Reich, P.B. 1993. Relative growth rate in relation to physiological and morphological traits for northern hardwood tree seedlings: species, light environment and ontogenetic considerations. Oecologia, 96: 219-231. 